\title{
A Comparative Approach to a Transatlantic Scandal: Le Monde and the New York Times' Coverage of Roman Polanski's 2009 Arrest
}

JULIA LEFKOWITZ, University Of Oxford ${ }^{1}$

\begin{abstract}
Since internationally renowned film director Roman Polanski was arrested on six charges of misconduct directed at a minor in 1977, his legal case has drawn strong reactions in connection to a range of political, social, and moral issues. Responses to the scandal have differed sharply across French and American national lines and as such, prestige press coverage of the director's 2009 arrest in France and the U.S. reflects differences in dominant national ideologies. This paper applies a critical discourse analysis (CDA) approach to analyze two specific sets of national ideologies connected to the case - those connected to that of the artist's worth and those relevant to perceptions of sexual misconduct.
\end{abstract}

\section{KEYWORDS}

Critical Discourse Analysis; French Journalism; U.S. Journalism; Comparative Analysis; Roman Polanski

\footnotetext{
${ }^{1}$ This paper was written while I was enrolled at the American University, where I completed my MA in Global Communications.
} 
"What's fascinating about the Polanski case is that it is not particularly about Polanski. ,2

This paper applies a critical discourse analysis (CDA) approach to analyse and compare U.S. and French newspaper coverage of filmmaker Roman Polanski's 2009 arrest. CDA is a key tool that enables analysis of media discourse by exploring the link between language and ideology. While ideologies have been defined in many different ways, this paper treats the concept as "representations which contribute to constituting, reproducing and transforming social relations of power and domination" (Fairclough 2010, 28). ${ }^{3}$

Coverage of Polanski's arrest in 2009 was selected for analysis in view of my interest in the scandal within a contemporary globalized media landscape. Herein, the U.S. is increasingly viewed as a hegemonic force (Albert 2004) and, within an increasingly post-national, postmodern context, the salience of dominant national ideologies merits examination.

While the Polanski scandal touches on a range of contentious topics, including sexual misconduct, the worth of an artist in a given culture, the responsibility of parents as guardians, and the dynamics of celebrity in a media-saturated culture, two topics were assessed for the sake of space and time. The worth given to an artist - is an artist above the law? - and concepts of sexual misconduct were selected in view of the particularly strong contrasts between pertinent dominant ideologies upheld in the U.S. and France, as depicted in academic literature.

\section{Polanski: Background}

Roman Polanski was born in Paris, France in 1933, and in 1936 his father, a Jewish emigré from Poland, decided to move his family back to Krakow. Six years later, both of Polanski's parents were sent to Auschwitz, where his mother was killed.

\footnotetext{
${ }^{2}$ Badt 2009, 1

${ }^{3}$ Drawing from Fairclough's work, the concept of national ideologies is discussed in greater detail in the "Critical Discourse Analysis" section of this paper.
} 
Shortly after having received an Academy Award nomination for Knife in the Water (1963), his first full-length feature film, Polanski moved to Hollywood and accepted an offer to direct Rosemary's Baby, which catapulted him to celebrity status. In January 1967, Polanski married actress Sharon Tate, who was brutally murdered by followers of Charles Manson less than two years later. At the time of her death, Tate was eight and half months pregnant.

Polanski continued to make movies, including the critically renowned Chinatown (1974). In 1977, he traveled to L.A. where he photographed 13 year-old Samantha Geimer for a French Vogue feature on adolescent girls. During a shoot, Polanski took Samantha to actor Jack Nicholson's house where he admittedly had sex with the 13 year-old. Geimer alleged that Polanski gave her champagne and a Quaalude, and raped her, and the filmmaker was subsequently charged with crimes on six counts.

A media frenzy accompanied the ensuing trial. On February 1, 1978, during a 90-day mental evaluation ordered by the case's presiding judge, Laurence J. Rittenband, Polanski took flight to London. He was thereafter declared a fugitive by the Los Angeles court and has since not returned to the U.S.

Polanski's attorneys and numerous other parties have and continue to accuse Rittenband of bias. A documentary released in 2008, "Roman Polanski: Wanted and Desired," presented new evidence suggesting that a clerk, who was also a friend of the judge, coached Rittenband to punish Polanski. The filmmaker's attorneys used the film in a suit to have charges against Polanski dropped; however, when Polanski did not attend a hearing that mandated his presence, the Los Angeles court rejected the request (Toobin 2009).

In 2008, Polanski started to direct the film The Ghost (later released in the States with the title The Ghostwriter). He had been working on the film for over a year when he was arrested in Switzerland by Swiss police acting on an official warrant issued by the U.S. days earlier. The arrest was received with expressions of surprise from Polanski, the media, and the public. Upon his apprehension, the director was immediately placed in provisional detention in Switzerland. 
Later, Polanski paid 4.5 million Swiss francs to serve house arrest at his estate in the Swiss ski resort town, Gstaad, while his case was reviewed by Swiss courts. In July 2010, the Swiss legal system rejected the U.S.'s extradition request, citing a technical error in the U.S.'s request and doubts as to the legality of Rittenband's conduct during the 1977 - 1978 trial.

\section{American and French National Ideologies}

French republicanism has often been contrasted with the Anglo-Saxon preference for liberalism (Livesey 2002). In line with this distinction, the relative emphasis on humanism and aesthetics in France contrasts with the relative prominence of Puritan and pragmatic priorities in the U.S.

Puritanism has been identified as a core, extant element of contemporary American ideology (Minguic 2010, Teachout 2009). In the seventeenth and eighteenth centuries, Puritan communities in America extolled moral law within both the private and public spheres, publically punishing individuals who deviated from the strict moral laws of the Bible. In a seeming paradox, Puritans also extolled material prosperity.

Pragmatism has similarly been cited as a core American value, supporting to the notion that America's roots are in the Bible, whereas Europeans' roots are in history (Minguic 2010). The prominent role of pragmatism has been correlated with the American tendency to appreciate art and intellectual practices that are scientific more than those which qualify as "high art" (Lamont 1992, 100). Scholars have also cited a general lack of appreciation for 'culture' in America.

In contrast, France has been known historically for its appreciation of art and cultural capital. "Aesthetics and philosophy are revered by the French" (Hall and Hall 1990, 93) and there is a tendency to "emphasize refinement and humanist culture" in France (Lamont 1992, 100). In response to the rise of a globalized mass media and widespread concern in the country over the potential pervasion of American media, 
legal measures, such as l'exception culturelle ${ }^{4}$, have been instituted in an attempt to sustain the presence of French cultural products.

Academic literature also notes the liberal attitude towards sexual behavior that is common in French culture. In an ethnographic survey on the topic, Lamont (1992) finds that French respondents "were not very concerned with promiscuity and deviant sexual behavior" (28). While such perceptions might vary as they are applied to men and women, heterosexual and homosexual relationships, French perspectives on sex are portrayed as particularly open in comparison to those common in the U.S. Lamont also explicitly identifies a French tendency to separate sexual behavior from morality $(1992,27)$.

Scholars have also acknowledged fundamental differences in American and French conceptualizations of privacy, which, further, manifest in certain laws upheld in each country. James Q. Whitman (2004) suggests that in France, notions of privacy tie into a national cultural appreciation of personal dignity, honour, and the individual's right to maintain their public image. According to Whitman, this understanding of privacy is the result of the influence of early modern aristocrats, which reflects the extant power of a privileged class that sees the media as a threat to privacy.

French law prevents against "les atteintes à sa présomption d'innocence", or "damage to the presumption of innocence", whereby certain practices which are commonplace in the U.S., such as perp walks, the publication of mug shots, and the naming of suspects, are outlawed. As similarly suggested through the widespread outrage expressed in France following the perp walk of Dominique Strauss Kahn in 2011, the U.S. ideologies pertinent to privacy, reflected in the American legal system and media, fundamentally contrast with the corresponding ideologies widely upheld in France.

\footnotetext{
${ }^{4}$ L'exception culturelle is a set of subsidies, tax breaks, and quotas that within France, to protect French cultural products, such as movies and music, from foreign competition. The policy was passed in 1993 through the General Agreement on Trade and Tariffs (GATT) negotiations, and can be said to reflect a French of view of cultural products as fundamentally different from commercial ones.

${ }^{5}$ http://www.legifrance.gouv.fr/affichCodeArticle.do;jsessionid=19C04F150E579BCAE87BE5E6305FF5 F5.tpdjo03v 1?idArticle=LEGIARTI000006574771\&cidTexte $=$ LEGITEXT000006071154\&dateTexte $=201$ $\underline{10106}$
} 
While rape laws differ from state to state in the U.S. and more broadly between the U.S. and France, at the time of the assault, Samantha Geimer qualified as a minor under both California and French laws. ${ }^{6}$ However, California penal codes identify a wider and more specific array of sexual offenses against minors ${ }^{7}$, whereas blanket terms such as "les agressions sexuelles autres que le viol" (sexual assault other than rape) are used in French law ${ }^{8}$. This disjunction can be said to reflect a more invested concern in the sexual purity of children in the U.S.

\section{Critical Discourse Analysis}

While CDA can be deployed as a methodological tool, the approach should also be understood as an attitude towards ideology, discourse, and power. This paper applies Norman Fairclough's approach to CDA, which emphasizes the capacity of dominant ideologies to be naturalized within discourse. While other proponents of CDA, such as Teun van Dijk, focus on relatively micro-level elements of the approach, such as cognitive elements of meaning and understanding, Fairclough stresses his interest in "the reproduction of social structures in discourse" whereby both the micro and macro are areas of focus $(1985,746)$.

'Social institutions' are identified as "an intermediate level of social structuring, which faces Janus-like 'upwards' to the social formation, and 'downwards' to social actions" $(1985,748)$. Media outlets are examples of social institutions, whereas a national culture is an example of a 'social formation,' a term through which Fairclough references "a particular society at a particular time and stage" (1985, 747). Drawing from Fairclough's definition of ideologies as "representations which contribute to constituting, reproducing and transforming social relations of power and

\footnotetext{
${ }^{6}$ In California, the age of consent was and remains 18, whereas the corresponding age in France was and remains 15 .

${ }^{7} \underline{\mathrm{http}}$ // www.leginfo.ca.gov/cgi-bin/displaycode?section=pen\&group=00001-01000\&file=261$\underline{269}$ and http://www.leginfo.ca.gov/cgi-bin/displaycode?section=pen\&group=00001$\underline{01000 \& \text { file }=281-289.6}$

${ }^{8}$ http://www.legifrance.gouv.fr/affichCode.do;jsessionid=66710DEC87D5DC9C8F17437D116D193B.tp djo03v 1?idSectionTA=LEGISCTA000006181754\&cidTexte=LEGITEXT000006070719\&dateTexte $=2006$ $\underline{0701}$
} 
domination" $(2010,28)$, discursive actions produced by a social institution within a given nation can thus be said to sustain the ideologies that underpin a national culture. While the notion of national ideology can be viewed as problematic, particularly in a contemporary globalized, postmodern, post-national context, numerous media scholars have attested to the continuation or amplification of manifestations of nationalism in mainstream media outlets (Rantanen 2012, Lefkowitz 2013).

The objective of CDA is to identify ideologies that might otherwise remain naturalized within any given instance of discourse. Properties such as lexis, syntactical variation, and agency attribution, for example, can serve as vehicles for the linguistic codes wherein ideologies are represented. CDA can thus combine any number of discursive criteria, such as lexis, photographs, layout, and syntax, as means through which to identify the ideological manifestations embedded in discourse.

\section{Methods}

The two newspapers examined, the New York Times and Le Monde, were selected in view of the similar socio-economic and ideological positioning of their respective readerships: readers of both tend to be well-educated members of the middle or upper class who are to the left side of the ideological spectrum.

Several differences between the two sets of articles should be briefly acknowledged. As Le Monde does not publish print editions on Sundays or Mondays, its first print article covering Polanski's arrest appeared on September 29; the NYT first reported on the story the day before. Whereas Le Monde ran three articles on the topic on the $29^{\text {th }}$ and one on the $30^{\text {th }}$, the NYT ran one article covering the arrest on both the $28^{\text {th }}$ and $29^{\text {th }}$. In essence, this approach should be considered synchronic. Le Monde's articles also had higher word counts than those featured in the NYT; the relative verbosity of the French language is factor to be taken into account.

Three criteria - headlines, lexis, and agency attribution - were selected and examined with regard to each topic. Overlap between these three criteria should be noted: for example, the analysis of word choice at times touches on that of agency attribution. 


\section{Worth Given to the Artist}

\section{Headlines}

Headlines generally serve to grab readers' attention and to give an overview of the story in a few words. Further, it can be considered that "what appears in the headline is usually considered the most pertinent and important information in the text" (Wang 2009, 749).

Polanski is the only actor referenced in either of the NYT's headlines. Further, neither headline mentions Polanski's identity as a filmmaker, while both reference his arrest. As such, the NYT's headlines spotlight Polanski's conflict with the law and do not draw attention to his identity as an artist.

In contrast, three of the four headlines in Le Monde either reference Polanski as a filmmaker or his association with the film industry. In this way Le Monde's use of language portrays Polanski first and foremost as a filmmaker, or artist. A headline featured in Le Monde on September 29, "Le Monde du cinéma se mobilize pour Polanski" (The film world mobilizes for Polanski), depicts Polanski as in a position where he needs the help of a powerful entity, and is someone for whom the "film world" will mobilize; Polanski is portrayed as a victim and someone whose achievements will incentivize the film industry to rally behind him.

\section{Lexis}

A lexical difference of note between the two sets of articles is Le Monde's repeated reference to Polanski as a "cinéaste." This word appears in two of the four headlines and features regularly in each article, with the exception of the first, very short one, where it is only used once. The frequency with which Le Monde refers to Polanski as a filmmaker underscores the newspaper's emphasis on his identity as an artist. This 
tendency is also reflected in Le Monde's reference to Polanski as "un artiste," a term that is used in two of its four articles; the word "artist" does not appear in the NYT.

On September 29, Le Monde depicts Polanski's status as a member of the prestigious Académie des beaux-arts, "Il vit à Paris, et a été élu membre de l'Académie des beaux-arts de l'Institut de France en 1998. Sa consécration definitive s'est concrétisée par le triomphe du Pianiste" (He lives in Paris, and was elected a member of the Academy of Fine Arts of the Institute of France in 1998. His final consecration was materialized by the triumph of The Pianist). While in French the word "consecration" is more commonly used in similar contexts, the publication's choice to use the word with reference to Polanski's admission to the Académie metaphorically attributes Polanski with a status of holiness, whereby he is more than just a common citizen. Inferred is the notion that other members of the Académie, or artists with comparable renown, have an elevated status.

While Le Monde repeatedly references Polanski as "le cinéaste," "un artiste," and "le réalisateur," the NYT refers to Polanski once as "the film director," once as "the director," and once as "the filmmaker" across its two articles. With the exception of these three references, Polanski is addressed as "Mr. Polanski." The NYT similarly uses honorifics to address other parties involved in the case, for example "Ms. Gibbons," a spokesperson for the L.A. County district attorney, and "Mr. Dalton," one of Polanski's attorneys. Polanski is in this way given the same status as the other individuals involved in the case.

The NYT also links Polanski's identity as a filmmaker to his identity as a French citizen. On September 28, both sentences referring to Polanski's French citizenship also mention that he is a filmmaker. One such instance states,

Famous as the director of 'Knife in the Water,' 'Repulsion' and other films - and as the husband of Sharon Tate, who was killed by the Manson crime family - Mr. Polanski, a French citizen, has long owned a home in Switzerland near the Gstaad resort. 
Post-modification of Polanski's name by his status as a French citizen suggests that each are a crucial and inherent part of Polanski's identity. Further, the films attributed to Polanski's status as a "famous" director are little-known in the U.S., thus suggesting that Polanski is closer to and better known in France.

Both Le Monde and the NYT also allude to financial elements of the scandal. The latter's September 28 article states, “Mr. Polanski's arrest could hinder the release of 'The Ghost.' Sales agents for the film have waited for Mr. Polanski to complete it before lining up a United States distributor." Polanski's filmmaking is thus depicted in line with its capacity to yield financial profits. Reference to the people who sell and distribute films in the U.S. further links Polanski with influential individuals who generate profit through film: attention is thereby drawn to Polanski as someone who himself has economic power. Thus, while renowned for his cultural capital in France, in the U.S., Polanski is recognized for his economic capital as a filmmaker connected to the American film market.

Le Monde refers to the 2008 UBS financial scandal $^{9}$ as the impetus for Polanski's seemingly sudden arrest in Switzerland. The article states that, “... la Suisse, après le désastreux scandale fiscal autour du géant bancaire UBS, s'etait empressée d'exécuter le mandat d'arrêt des Etats-Unis" (Switzerland, after the disastrous banking scandal involving the banking giant UBS, was eager to execute the United States' arrest warrant). The adjectives "disastrous" and "giant" amplify the magnitude of the scandal and its consequences, sensationalizing the implied greed of the U.S. and Switzerland. The latter is, however, both aligned with and depicted as subservient to the U.S.

A final point of note is the presence of negatively charged language in the direct discourse of notable politicians, writers, and filmmakers included in each publication. Le Monde quotes Frédéric Mitterand, France's Minster of Culture, describing Polanski's arrest as "absolument épouvantable," or "horrifying." Robert Harris, the

\footnotetext{
${ }^{9}$ A U.S. Senate panel report issued in 2008 accused UBS of encouraging wealthy Americans to avoid taxes through offshore accounts. The Swiss bank ultimately paid the U.S. Securities and Exchange Commission a \$220 million settlement, and following a dispute that ensued between the U.S. and Swiss governments, Swiss banking laws were later changed to allow the release of client data and account details of U.S. citizens suspected of tax evasion.
} 
author of the book "The Ghost," from which Polanski's most recent film was adopted, is quoted as being "stupéfait." The "horror" of the French Minister of Culture and "stupification" of an intellectual closely connected with Polanski in effect depicts the filmmaker's arrest as a shocking offence to those who contribute to and sustain art that is appreciated in France.

The NYT includes statements from a current and a former member of the French government, both of whom strongly criticize Polanski's arrest. Both are included in the September 29 article, and the second such quote is of particular interest,

Jack Lang, a former French culture minister, said that for Europeans the development showed that the American system of justice had run amok.

'Sometimes, the American justice system shows an excess of formalism,' Mr. Lang said, 'like an infernal machine that advances inexorably and blindly.'

Lang uses the metaphor of "an infernal machine," to depict the U.S. legal system as one which, further, shows an "excess of formalism." Suggested is the notion that "American justice" is separate from emotion and even from reality, as it is a machine that advances "blindly." Perhaps Lang was aware of his play on words, as the American legal system in fact prides itself on practicing "justice that is blind," or without bias. If Lang is aware that this notion is an integral part of the American justice system, he is condemning the system at its core. Lang's statement can be said to reflect a dominant notion of how Americans believe they are perceived in France, which will be discussed further in the "Conclusions" section.

\section{Agency}

Le Monde frequently deploys the passive voice to deflect culpability away from Polanski. An example of this tactic is, "il lui est reproché d'avoir eu des rapports sexuels avec une mineur de 13 ans..." (he is accused of having sex with a thirteen year-old minor). Use of the passive voice depicts Polanski as having been accused of certain acts, or someone who has been imposed upon. 
Conversely, the publication's use of agency designates Polanski's credit for films that are the product of his personal experience and talent. The third article featured in $L e$ Monde on September 28, which contains an overview of Polanski's work states,

Juif polonais, il a assisté à la construction du ghetto de Cracovie et à l'élimination des juifs qui y étaient emmurés, avant de parvenir à s'en échapper. Un film, Le pianiste, Palme d'Or au Festival de Cannes en 2002, témoigne de ce cauchemar.

A Polish Jew, he witnessed the construction of the Krakow ghetto and the elimination of Jews who were entombed there, before managing to escape. A film, The Pianist, winner of the Palme d'Or at the Cannes Film Festival in 2002, is a testimony to this nightmare.

Le Monde attributes agency to Polanski as someone who was a victim of the Holocaust, "il a assisté à la construction du ghetto." Subsequently, it was reported that The Pianist, which was informed by Polanski's horrible experience, or "nightmare," was honoured with the Palme d'Or at Cannes. Accordingly, the Palme d'Or is depicted as inherently linked to Polanski and his life experiences. In the remainder of this article, agency is deployed to a similar end, and other articles by the publication similarly use this type of syntactic construction to underscore the power of Polanski's talent.

In contrast to Le Monde, the NYT's use of agency portrays Polanski as a sexual culprit. This is exemplified through the brief but detailed overview of the charges against Polanski conveyed in the NYT"s September 28 article: "He eventually pleaded guilty to one count of having sex with a minor but left the country after becoming convinced he would be sent back to jail after having a 42-day psychiatric evaluation in state prison." The publication's use of agency portrays Polanski as responsible for having sex with a minor and fleeing the U.S to avoid prison-time; Polanski's guilty plea is not referenced by Le Monde. 
In the NYT, agency designation accompanying references to Polanski's work generally portrays a distance between Polanski and his films. For example, the newspaper's September 29 article states, "When in Germany directing his latest film, 'The Ghost,' Mr. Polanksi occasionally avoided the set..." Similarly, the publication's September 28 states, “... when he won an Oscar for directing 'The Pianist,' he did not attend the ceremony." (While Polanski was precluded from attending because of the standing charges against him, a gap between the director and his work is still depicted through the reference to his absence). Trends in the NYT's use of agency can be said to reflect the publication's view of Polanski as, first and foremost, an offender of moral and legal standards upheld in the U.S.

\section{Perceptions of Sexual Misconduct}

\section{Headlines}

Of the seven articles from Le Monde and the NYT, only one story headline refers to the nature of the charges against Polanski. This reference is contained in a subheadline to a September 29 article published in Le Monde that states, "Poursuivi pour agression sexuelle, il y a plus de trente ans, le cinéaste pourrait être extradé vers les Etats Unis" (Charged with sexual assault more than thirty years ago, the film-maker could be extradited to the United States). While the headline could have drawn more attention to the nature of the referenced sexual assault, which was directed at a minor who was given alcohol and drugged, attention is instead dedicated to the prospect of Polanski possibly being extradited after "more than thirty years."

While neither of the NYT's headlines mentions the exact charges against Polanski, both headlines reference his arrest, subsequently alluding to Polanski's interference with the law. Furthermore, both headlines also name Polanski, which effectively puts the spotlight on him and no one else.

\section{Lexis}


Both articles in the NYT reference the six charges filed against Polanski (Furnishing Drugs to a Minor, Lewd or Lascivious Acts upon a Child under 14 year of Age, Unlawful Sexual Intercourse, Rape by Use of Drugs, Perversion, and Sodomy) and make clear that the victim of these alleged offences is a 13-year-old girl. While neither article lists all six charges, both mention those of rape and sodomy, which can be considered the most sexually explicit and physically abusive of the alleged offenses; Polanski is thus depicted as a lewd perpetrator of crimes against a young girl.

The last sentence of the September 29 article provides more information on Geimer's attitude towards Polanski. It states, "The victim in the case, Samantha Geimer, has long publicly identified herself and expressed forgiveness of Mr. Polanski.” Thus, while Le Monde portrays Polanski as the victim, the NYT explicitly identifies the 13 year-old girl as the victim. While Geimer has expressed forgiveness of Polanski, she has done so "publically" which leaves open the question of whether or not she has forgiven Polanski outside of the media spotlight.

Le Monde references the charges against Polanski in highly generalized terms. Examples of the relevant lexicon include, "aggression sexuelle," "rapport consenti selon Polanski, force selon la mineure" (relations which, according to Polanski, were consensual, and which, according to the minor, were forced) "relations sexuelles avec une mineure" and "rapports sexuels ave une mineure de 13 ans." Words such as "aggression," "rapport," and "relations" in effect serve as euphemisms that gloss over the specifics of Polanski's brutal actions. The filmmaker's offenses are thus downplayed, which can be said to reflect a casual mentality towards his sexual conduct.

Le Monde uses quotes to draw attention to what it perceives to be American and Swiss conceptualizations of sexual misconduct. A September 29 article states, "De plus, 'les délits sexuels contre les enfants' sont imprescriptibles en Suisse comme aux Etats-Unis [...]" (Moreover, 'sexual offenses against children' are imprescriptible in Switzerland, as they are in the United States [...]). The publication's use of quotes underscores the concept of "crimes against children" as distant from the corresponding French mentality. Similarly, the September 30 article states, "Dans une 
Amérique où sont fortement dénoncés les crimes pédophiles,' Hollywood n'a quasiment pas réagi dépuis l'arrestation de Polanski" (In an America where paedophile crimes are strongly denounced, Hollywood has barely reacted to Polanski's arrest). "Paedophile crimes" are thus similarly depicted as foreign, upheld by a country whose film industry has not reacted with anger to Polanski's arrest (in fact dozens of Hollywood actors, directors, and filmmakers signed a petition in support of Polanski's release less than a day after his arrest).

The publication's use of the term "affaire de mœurs" to characterize the Polanski affair is also of interest. An article featured in the newspaper on September 29 states, "Roman Polanski, désormais sous la menace d'une extradition vers les Etats-Unis, se voit rattrapé par une affaire de mœurs qui remonte à plus de trente ans" (Roman Polanski, already under threat of extradition to the United states, is being caught up in an affair of mores dating back more than thirty years). In describing Polanski as "caught in an affair of mores," the filmmaker is explicitly portrayed as being imposed upon by an American system: in this case, that of manners, or moral attitudes.

\section{Agency}

The examples discussed in my paper's section on agency related to the topic of an artist's worth overlap with agency use related to the theme of sexual misconduct. In Le Monde, these examples showed the use of the passive voice to deflect culpability away from Polanski. Further, the publication's use of agency portrays parties other than Polanski as culprits. For example, an article from September 29 states, "Une piège lui a été tendu; il est tombé dedans" (A trap was laid for him: he fell in). The previous sentence in the article references the U.S.; Polanski is thus depicted as merely having fallen into the "trap" set up by the U.S. Le Monde attributes agency to other parties to similar ends in articles from both September 29 and 30.

On the subject of sexual misconduct, the $N Y T$, in contrast, attributes agency to Polanski in contexts whereby he is effectively portrayed as a sexual culprit. At no point does the publication use agency to deflect responsibility to another party. 


\section{Conclusions}

The results of the CDA suggest several key conclusions about the national ideologies embedded in the discourse of the NYT and Le Monde.

Le Monde depicts an artist as someone who has abilities that make him superior to the common man and above certain laws. It is important to note that the law in the case of Polanski is the American law. As such, one must consider the following question: does Le Monde's audience see Polanski as above the American law or above all laws?

Le Monde's distanced references to "les délits sexuels contre les enfants" and "les crimes pédophiles" suggest that Polanski is above any law that punishes sexual misconduct towards a 13 year-old girl. It can thus be inferred that Polanski is seen as above any law that would incriminate him, which could include French law.

Further, Le Monde portrays Americans and the American legal system as trying to impose their ways upon Polanski. This notion may be tied to French fears of American cultural imperialism, which, as indicated by l'exception culturelle, are particularly pertinent to the arena of French cinema. In this sense, within the contemporary era of an increasingly globalized media, for Le Monde, the 2009 arrest of Polanski serves as something of an allegory for French opposition to the increasing pervasion of American culture; Polanski is depicted as the victim of this threat.

The idea that America has trapped and imposed upon a great artist, who was even "consecrated" to an elite academy in France, conveys America as a force that has used its power in an attempt to imprison a French citizen with divine powers. This is an anti-American sentiment.

The newspaper's reference to the Polanski case as "une affaire de mœurs" reflects a view of morality as a dominant element of American culture. This evokes notions of Puritanism, particularly the Puritan practice of punishing those who had deviated from accepted standards of sexual behavior. Le Monde's coverage of Polanski's arrest portrays a perception of America as a Puritan culture, implicitly contending that, in 
France, such "mores" are not upheld; the French tendency to view sexual conduct as unattached to morality, as identified by Lamont (1992), can be detected.

While culture is a theme that receives more attention in Le Monde than in the NYT, the latter's use of language and syntax conveys a perception of French culture as highly intellectual and morally liberal. In line with the connection drawn between Polanski's identity as a French citizen and his identity as a filmmaker, it is suggested that Polanski's films are appreciated for their artistic value in France more than in America, where films are viewed as a commodity. The publication's use of Lang's highly poetic statement regarding the American justice system also more explicitly depicts a link between French cinema and intellectual activity and appreciation. This portrayal brings attention to the NYT's ideological emphasis on material prosperity and also puts into question the publication's appreciation of cultural capital, particularly that which is of French and more broadly, foreign origins.

The NYT's use of statements from a current and a former member of the French government that strongly criticize Polanski's arrest suggests a perception of French ideology as one that supports Polanski and condemns American values. As the NYT acknowledges the appreciation of Polanski's work in France, the publication can be said to depict a connection between French cultural appreciation and its belief that Polanski should not be punished for his behavior. Accordingly, it can be said that the NYT sees the French system of values as one wherein artists are exempt from the law.

This study and its conclusions could be examined further through adding new elements for comparative analysis. One such approach could compare the language in the coverage of Polanski's 2009 arrest with that of coverage of the scandal when it first broke in the late 1970s. This would be a particularly interesting forum in which to assess the possible amplification of fears of American cultural imperialism and more broadly, diachronic differences in the mediation of national ideologies and Othering within both the French and U.S. contexts. Coverage of a contemporary transatlantic scandal, such as that surrounding the 2011 arrest of Dominique StraussKahn, could also be used as a point of comparison through which to examine differences between the treatment of a French artist and a French politician accused of sexual misconduct in the U.S. 


\section{References}

(2009) 'Le monde du cinéma se mobilise pour Polanski,' Le Monde 29 September.

Badt, L.K. (2009) 'Roman Polanski', Bright Lights Film Journal, November, 1-4.

Blain, M. (2005) 'The Politics of Victimage: Power and subjection in a US anti-gay campaign', Critical Discourse Studies, 2, April, 31-50.

California Penal Code Section 261.5 [online]. Available at http://law.onecle.com/california/penal/261.5.html. Accessed on 30 December 2014.

California Penal Code Section 281 - 289.6 [online]. Available at http://www.leginfo.ca.gov/cgi-bin/displaycode?section=pen\&group=0000101000\&file $=281-289.6$. Accessed on 30 December 2014.

Cieply, M. and Barnes, B. (2009) 'Polanski's Arrest Could Lead to Extradition,' The New York Times 28 September.

Cieply, M. and Jolly, D. (2009) 'Question in Polanski Arrest: Why Now?' The New York Times 29 September.

Code pénale [online]. Available at http://www.legifrance.gouv.fr/affichCode.do;jsessionid=66710DEC87D5DC9C8F 17437D116D193B.tpdjo03v_1?idSectionTA=LEGISCTA000006181754\&cidText $\underline{\mathrm{e}=\text { LEGITEXT000006070719\&dateTexte }=20060701}$. Accessed on 30 December 2014.

Code de procédure pénale [online]. Available at http://www.legifrance.gouv.fr/affichCodeArticle.do;jsessionid=19C04F150E579B CAE87BE5E6305FF5F5.tpdjo03v_1?idArticle=LEGIARTI000006574771\&cidTe $\underline{\text { xte }=\text { LEGITEXT000006071154\&dateTexte }=20110106}$. Accessed on 30 December 2014.

Douin, J.L. (2009) 'L'indignation en France, un pays où le cinéaste s'était installé il y a trente ans,' Le Monde 29 September.

Duparc, A. and Mulard C. (2009) 'Les différents scenarios après l'arrestation de Roman Polanski en Suisse,' Le Monde 29 September.

Fairclough, N. (1985) 'Critical and Descriptive Goals in Discourse Analysis', Journal of Pragmatics, 9, 739-763. 
Fairclough, N. (1995) Critical Discourse Analysis: the Critical Study of Language, London: Longman.

Hall, E.T. and Hall, M.R. (1990) Understanding Cultural Differences: Germans, French and Americans, Yamouth: Intercultural Press, Inc.

Lamont, M. (1992) Money, Morals, and Manners: The Culture of the French and American Upper-Middle Class, Chicago: The University of Chicago Press.

Lefkowitz, J. (2013) 'The Dominique Strauss-Kahn Scandal: Mediating Authenticity in Le Monde and the New York Times', in J. Petley (ed.), Media and Public Shaming: Drawing the Boundaries of Disclosure, I.B. Tauris in association with the Reuters Institute for the Study of Journalism, University of Oxford: London, pp. 145-164.

Livesey, J. (2001) 'The Culture and History of French Republicanism: Terror or Utopia ?' The Republic, 1(2), 47-71.

Mingiuc, A. (2010) 'Key Concepts in Puritanism and the Shaping of the American Cultural Identity', Philologica Jassyensia, 6, 211-217.

Mulard, C. (2009) 'Pour les Etats-Unis, Polanski, c'est trente ans de cavale...,' Le Monde 30 September.

Orpin, D. (2005) 'Corpus Linguistics and Critical Discourse Analysis: Examining the ideology of sleaze', International Journal of Corpus Linguistics, 37-61.

Rantanen, T. (2012) 'In Nationalism We Trust?’ in M. Castells, J. Caraça, and G. Cardoso (eds), Aftermath: the Cultures of the Economic Crisis, Oxford: Oxford University Press, pp. $132-153$.

Teachout, T. (2009) 'Our Creed and Our Character', Commentary, 124, July-August, $62-65$.

Toobin, J. (2009) 'The Celebrity Defense,' New Yorker, 85, 14 December, 50-63.

Wang, H.C. (2009) 'Language and ideology: gender stereotypes of female and male artists in Taiwanese tabloids', Discourse \& Society, 20, November, 747-774.

Julia Lefkowitz is a DPhil candidate at the University of Oxford. Her doctoral thesis examines recent putative shifts in British tabloid and 'quality' newspapers through a combination of corpus linguistic and discourse analytic methods. Her work has also 
been published by I.B. Tauris in association with the Reuters Institute for the Study of Journalism.

Email: julia.lefkowitz@gmail.com or julia.lefkowitz@pmb.ox.ac.uk 